\title{
Sistem Informasi Hutang Piutang (Studi Kasus:Perusahaan XYZ)
}

\author{
Eko Purwanto ${ }^{1)}$, Hanifah Permatasari ${ }^{2)}$ \\ ${ }^{1}$ Univesitas Duta Bangsa, ${ }^{2}$ Univesitas Duta Bangsa \\ ${ }^{1} \mathrm{Jl}$. Bhayangkara No. $55,{ }^{2} \mathrm{~J}$. Bhayangkara No. 55 \\ 1'eko purwanto@udb.ac.id, ${ }^{2}$ hanifah_permatasri@udb.ac.id
}

\begin{abstract}
Abstrak
$\mathrm{XYZ}$ Company in the process of delivering receivable payable information is done by the way, the Director came directly to the company to know the due date receivable payable still using the manual system by admin seeing the accounts payable one by one. As a result, the information of due date receivable payables is less quickly submitted to the owner of the company.

The puspose of designing and building a system of receivable payable information on Batik Rahmawati Company is, that the system expected would provide quickly and correctly information to the company.

In this research, the researcher proposed the use of web-based accountspayable information system to provide receivable payable information to owner and the due date of receivable payable information of the accounts payable to the supplier or customer. The system that has been used is developed to computerize based (towards computerization) by using online web and using the waterfall development system method and by using designtools DFD (Data Flow Diagram).

The testing is done by using Black box test which gives result that the web run as expected. The testing user who gives result agrees thet the system of the receivable payable information is feasiable and could help the user knowing the amount of the due date receivable payable. The conclusion of we-based receivable payable system is, that application could facilitate easilythe owner, suppliers, costomers of XYZ Company to know the receivable payable.
\end{abstract}

Keywords:receivable, payable, information, due date of the, supplier, customer.

\section{PENDAhuluan}

Pencatatan hutang-piutang merupakan hal yang harus diperhatikan oleh perusahaan yang mengadakan pembelian dan penjualan secara tempo. Hal tersebut dikarenakan piutang merupakan salah satu unsur aktiva lancar yang nilainya relatif besar dan mempunyai resiko yang tinggi sehingga apabila tidak dicatat dengan baik, managemen akan mengalami kesulitan dalam mengambil keputusan sehingga dapat mengakibatkan kerugian atas penjualan secara tempo kepada pelanggan. Sedangkan hutang merupakan kewajiban perusahaan kepada pihak lain yang belum terpenuhi dan merupakan sumber dana atau modal perusahaan.

Perusahaan XYZ adalah perusahaan yang hampir aktivitas pembelian dan penjualannya dilakukan secara tempo. Untuk itu dibutuhkan prosedur pengelolaan hutangpiutang yang baik dengan sistem pencatatan dan pengendalian yang tepat.
Menurut observasi yang penulis lakukan dalam pencatatan hutang-piutang masih sangat sederhana yaitu dengan cara mencatat hutang-piutang ke dalam buku besar dan ke dalam kartu hutang-piutang dari masing-masing supplier maupun customer. Pemilik perusahaan merasa kesulitan dalam mengetahui nominal hutang-piutang yang dimilikinya, terlebih jika pemilik sedang berada di luar kota maupun luar negeri.

\section{METODE PENELITIAN}

Metodologi penelitian ini adalah caracara yang ditempuh dalam melaksanakan penelitian guna mengumpulkan data-data untuk penyusunan program.

1) Observasi

Metode observasi adalah sistem pengumpulan data dengan cara melakukan pengamatan secara langsung pada objek yang diteliti, sehingga didapat data yang akurat. Penulis mengambil data dengan 
melakukan kegiatan pengamatan langsung pada Perusahaan XYZ yang berkaitan dengan masalah Hutang Piutang.

2) Interview

Penulis memperoleh data dengan melakukan kegiatan berdiskusi dengan pimpinan Perusahaan XYZ untuk memperoleh data mengenai Hutang Piutang.

3) Studi Pustaka Penulis mengumpulkan data dengan mencari informasi yang berkaitan dengan Hutang Piutang yang berasal dari buku referensi dan dokumen lainnya yang berkaitan dengan Hutang Piutang.

4) Metode Pengembangan Sistem waterfall adalah sebuah model perkembangan perangkat lunak dilakukan secara sekuensial, dimana satu tahap dilakukan setelah tahap sebelumnya selesai dilaksanakan. (Roger S. Pressman, 2010).

a. Analisis Sistem

Penulis melukan analisis kebutuhan. Adapun kebutuhan untuk mencapai tujuan peneliti yaitu untuk merancang aplikasi hutang piutang maka dibutuhkan data dari Perusahaan XYZ yaitu berupa data manajemen informasi hutang, manajemen piutang, manajemen perusahaan, manajemen pelanggan, dan managemen pemasok. Penyampaian informasi hutang piutang yang digunkan masih mengunakan sistem yang biasa yaitu dengan cara di catat manual di buku hutang maupun piutang kemudian diinputkan ke aplikasi desktop. Oleh karena itu, dirancang sebuah aplikasi hutang piutang berbasis web dan alat perancangan dengan Data Flow Diagram (DFD).

b. Analisis

Pada tahap ini penulis membuat rancangan yang meliputi analisis sistem, desain sistem dengan menggunakan alat bantu Diagram Arus Data, merancang basisdata, merancang antarmuka sistem informasi hutang piutang.

c. Pembuatan Sistem

Pada tahapa ini dilakukan pembuatan suatu aplikasi berdasarkan perancangan sistemyang diusulkan.

d. Pengujian Sistem
Dalam fase ini ada beberapa hal yang perlu dilakukan. Ada dua jenis tindakan yaitu testing dan instalasi. Testing yaitu menguji hasil kode program yang telah dihasilkan dalam tahapan desain fisik. Pada tahap ini, proses testing program dilakukan dengan metode Black Box. Sedangkan instalaasi adalah tahapan yang dilakukan setelah pemrograman lulu uji coba dengan menginstal software dan hardware pada perusahaan dan resmi mulai digunakan untuk menggantikan system lama. Output dari tahapan ini adalah source code eror, prosedur pelatihan dan buku panduan.

e. Implementasi Program

Pada Tahap ini penulis melakukan implementasi program sistem informasi hutang piutang. Perbaikan yang dilakukan tingkatannya bisa sangat variatif, mulai dari memperbaiki program yang crash hingga berfungsi kembali sampai pada penambahan modul - modul program yang baru sebagai jawaban atas perubahan kebutuhan penggunanya.

\section{TINJAUAN PUSTAKA}

Sistem merupakan sekelompok komponen yang saling berhubungan dengan batasan yang jelas serta bekerja sama menuju tujuan tertentu dengan menerima input serta menghasilkan output yang merupakan fungsi dasar dalam proses transformasi yang teratur (O’Brien, 2013).

Hutang usaha merupakan suatau kewajiban yang harus dibayarkan untuk barang atau jasa yang telah diterima atau dipasok dan telah dilakukan penagihan dengan menggunakan faktur atau telah disepakati oleh pemasok secara formal (Ikatan Akuntan Indonesia, 2012).

Hutang jangka pendek atau biasa disebut dengan hutang lancar karena sumber hutang jangka pendek dipakai untuk mendanai kebutuhan-kebutuhan yang sifatnya mendukung aktivits perusahaan yang segera dan tidak bisa ditunda (Fahmi,2013).

Hutang jangka panjang yang biasa disebut dengan hutang tidak lacar (non current liabilities), karena dana yang dipakai dari sumber utang ini dipergunakan untuk 
membiayai kebutuhan yang bersifat jangka panjang (Fahmi, 2013).

Piutang adalah suatu tagihan terhadap kosumen yang muncul karena adanya penjualan barang atau jasa secara kredit. Piutang juga dapat diartikan suatu hak suatu perusahaan untuk menagih kepada pihak lain atas uang, barang atau jasa secara kredit (Reeve, Warren, Duchac, 2012).

Sistem Aplikasi Hutang Piutang adalah sistem yang mampu mengelola setiap transaksi hutang piutang atas barang produksi(Ayuni R A, dkk, 2017).

Sistem Informasi Pancatatan Hutang Piutang dapat mempermudah proses pencatatan penghasilan dan piutang dengan benar Dhanar I.S.S, dkk, 2014).

Aplikasi Sistem pengelolaan data hutangpiutang dagang dapat memudahkan dalam mengelola pembayaran hutang pelanggan. (Dian D.H, dkk, 2017).

Sistem pengolahan data Hutang Piutang berbasis komputer yang sistematis dan terarah,sehingga mampu membantu kinerja perusahaan menjadi lebih cepat, efektif dan efisien (Agus Setiawan, 2016).

\section{HASIL DAN PEMBAHASAN}

\section{1) Analisis Sistem}

Sistem Informasi yang dirancang akan mempermudah penyampampaian informasi data hutang-piutang kepada pemilik perusahaan XYZ. Penyampaian informasi tersebut akan otomatis update jika admin memperbarui data transaksi di database. Dari sistem ini jika ada transaksi baru maka pemilik akan mendapatkan informasi jika pemilik terhubung dengan internet. Untuk lebih memahami sistem yang dikembangkan dapat dilihat pada gambar 1 .

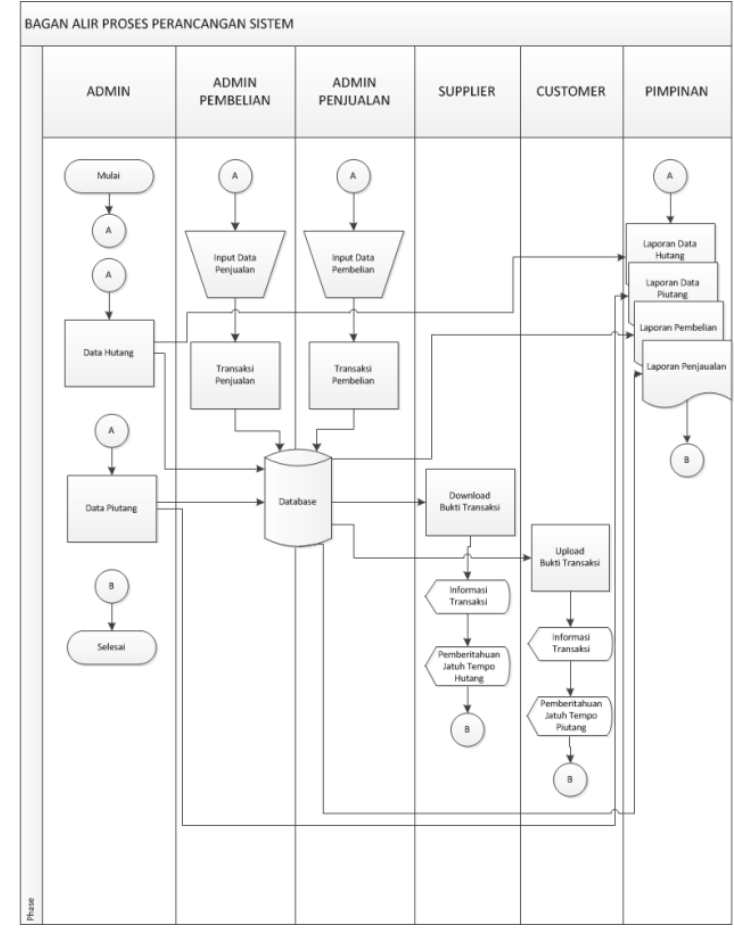

Gambar 1 Bagan Alir Proses pengecekkan Hutang-Piutang Pada Sistem yang Dirancang

\section{2) Desain Sistem}

Meninjau dari hasil analisis, maka sebagai tindak lanjut bagi penyelesaian masalah tersebut dapat dibuat suatu aplikasi yang mampu memberikan solusi bagi pemilik Perusahaan, supplier, dan customer dalam penyampaian informasi hutang-piutang secara cepat, tepat dan efisien.

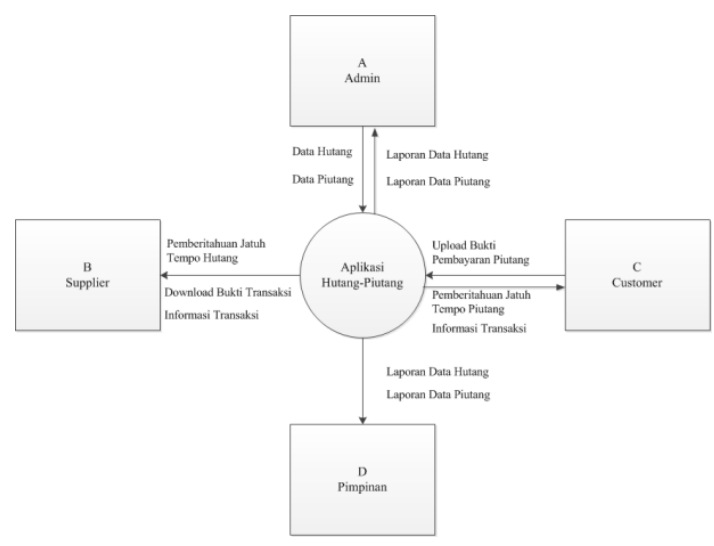

Gambar 2 Diagram Konteks

Diagram konteks di atas menjelaskan proses pengolahan data yang berjalan di Perusahaan XYZ. Dimulai dari admin input hutang, data piutang, data pembayaran piutang oleh customer. Selanjutnnya dari aplikasi hutangpiutang akan memberikan data jatuh tempo hutang-piutang ke supplier dan customer. 
Selain itu laporan yang dihasilkan diantaranya laporan data hutang dan laporan data piutang.

Entity Relation Diagram (ERD) aplikasi hutang-piutang pada Perusahaan XYZ yang mengunakan database MYSQL.

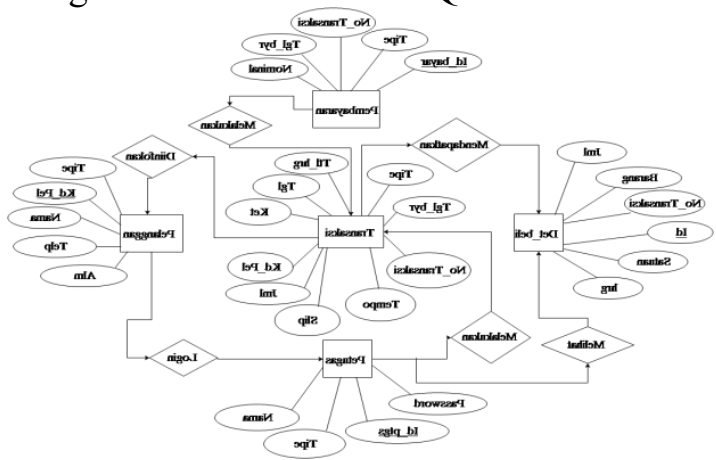

Gambar 3 ERD Aplikasi Hutang-Piutang

\section{f. Implementasi Sistem}

1) Implementasi database

Hasil dalam implementasi basis data dalam aplikasi Hutang-Piutang yang menggunakan MYSQL.

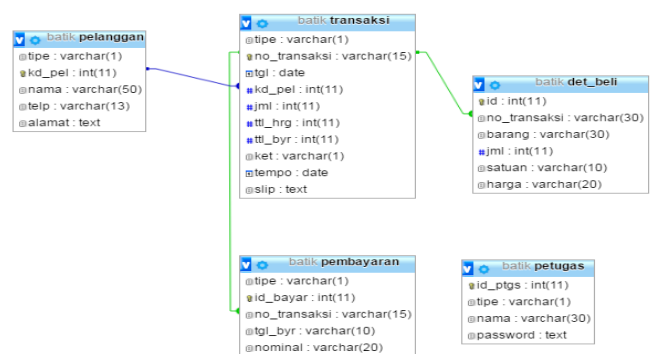

Gambar 4 Tampilan implementasi basis data

\section{2) Implementasi Program}

Pada tahap ini akan dijelaskan tentang implementasi penggunaan aplikasi hutangpiutang.
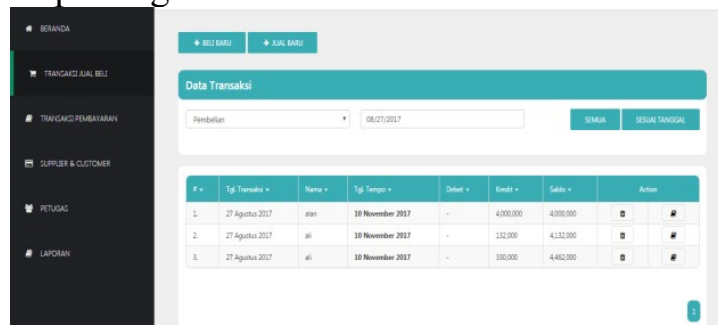

Gambar 5 Interface Form Menu Transaksi Jual-Beli
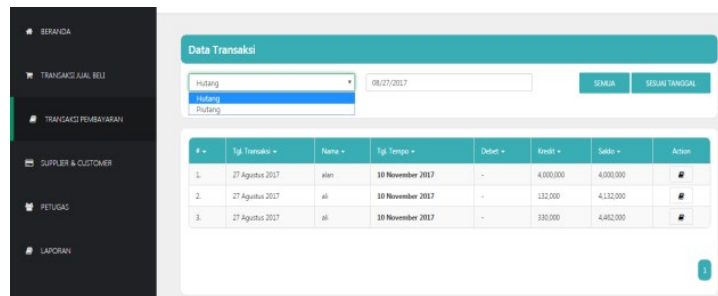

Gambar 6 Interface Transaksi Pembayaran

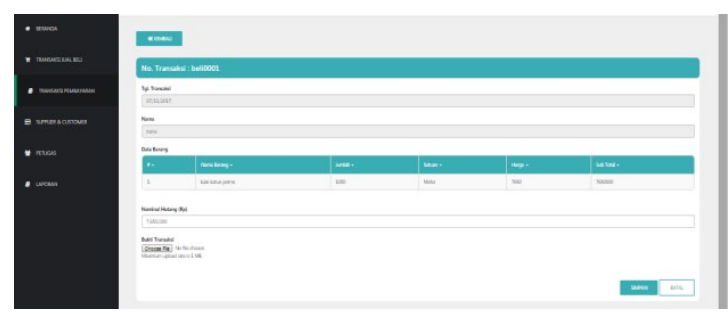

Gambar 7 Interface Detail Transaksi Pembayaran

\section{g. Hasil Pengujian}

Berdasarkan hasil pengujian dengan pengujian alpa, beta dan pengujian pada sistem web hutang-piutang dapat disimpulkan bahwa aplikasi menghasilkan keluaran seperti yang diharapkan dan aplikasi hutang-piutang dapat berjalan sesuai yang diharapkan. Aplikasi hutang-piutang layak dan dapat membantu dalam memberikan informasi hutang-piutang supplier dan customer.

\section{PENUTUP \\ a. Kesimpulan}

Sistem Informasi Hutang Piutang ini memiliki dua hak akses yaitu admin sebagai pengelola sistem dan user sebagai pengguna sistem. Aplikasi hutang-piutang ini mencakup pemberitahuan hutang-piutang yang jatuh tempo kepada setiap customer maupun supplier, pengelompokan informasi hutangpiutang sesuai id user, pembayaran hutangpiutang sesuai id user. Dan cetak laporan bulanan yang dilakukan oleh pimpinan.

\section{b. Saran}

Menyarankan untuk peneliti berikutnya agar sistem informasi hutang piutang ini dapat dikembangkan menjadi sistem informasi akuntansi serta dapat mengembangkan menjadi sistem informasi akuntansi.

\section{REFERENSI}

Agus Setiawan. (2016). Aplikasi Pengelolaan Barang dan Hutang Piutang Pada PT. Maju Anugerah Jaya Utama Banjarmasin. Jurnal Ilmiah Falultas Teknik "Technologia" Vol 7, No.1, Januari - Maret 2016

Ayuni R A, Hajijah, Lina Arliana \&Tio Ria Pasaribu. (2017). Membangun Sistem Aplikasi Hutang Piutang Pada Koperasi Karyawan Makmur Niaga PT. Wika Beton Sumut Tbk Sebagai 
Solusi Menghindari Kesalahan

Pancatatan. MAIKA(Majalah Ilmiah

Kaputama), ISSN 2548-9720. Vol. 1

No.2.

Dhanar I.S.S, Deny B.F. (2014). Sistem Informasi Pencatatan Hutang Piutang Pada Usaha Kecil Menengah. Jurnal Probisnis Vol.7 No.1.

Dian D.H, Wawan W, Patrick A.T. (2017). Aplikasi Inventory Barang, Pengelolaan Data Hutang Piutang Dagang dan Prediksi Kebutuhan Barang dengan Metode Single Exponetial Smoothing. eProceeding of Applied Science: ISSN: 2442-5826 Vol.3, No.2.

Fahmi, Irham. (2013). Analisis Laporan Keuangan. Bandung: Alfabeta.

Ikatan Akuntan Indonesia. (2012). Standar Akuntansi Keuangan. Jakarta: IAI

O'Brien A. James, Marakas, M. George. (2013). Management Information Systems. Salemba Empat.

Pressman, Roger S. (2010). Rekayasa Perangkat Lunak: Pendekatan Praktisi. Yogyakarta: ANDI

Reeve, M. James. Warren, S. Carl., Thomson, Duchac, E. Jonathan. (2013). Principles Of Accounting. Cengage Learning. 